\title{
Diagnosis and Treatment of Attention-Deficit Hyperactivity Disorder in Patients with Chronic Pain
}

\author{
Satoshi Kasahara', Yumiko Okamura' ${ }^{2}$, Ko Matsudaira ${ }^{3}$, Hiroyuki Oka ${ }^{3}$, Yoshie Suzuki', \\ Yasuko Murakami ${ }^{4}$, Toshiharu Tazawa ${ }^{5}$, Hayato Shimazaki6, \\ Shin-ichi Niwa ${ }^{7}$, Yoshitsugu Yamada ${ }^{1}$
}

\author{
${ }^{1}$ Anesthesiology and Pain Relief Center, Faculty of Medicine, University of Tokyo, Tokyo, Japan \\ ${ }^{2}$ Department of Neuropsychiatry, Faculty of Medicine, University of Tokyo, Tokyo, Japan \\ ${ }^{3}$ Department of Medical Research and Management for Musculoskeletal Pain, 22nd Century Medical and Research Center, \\ Faculty of Medicine, University of Tokyo, Tokyo, Japan \\ ${ }^{4}$ Department of Anesthesiology and Pain Medicine, Faculty of Medicine, Juntendo University, Tokyo, Japan \\ ${ }^{5}$ Department of Anesthesiology and Pain Medicine, Yokohama City University Medical Center, Yokohama, Japan \\ ${ }^{6}$ Department of Psychiatry, Jikei University School of Medicine, Tokyo, Japan \\ ${ }^{7}$ Department of Psychiatry, Aizu Medical Center, Fukushima Medical University, Fukushima, Japan \\ Email: namahage@king.odn.ne.jp
}

How to cite this paper: Kasahara, S., Okamura, Y., Matsudaira, K., Oka, H., Suzuki, Y., Murakami, Y., Tazawa, T., Shimazaki, H., Niwa, S. and Yamada, Y. (2017) Diagnosis and Treatment of Attention-Deficit Hyperactivity Disorder in Patients with Chronic Pain. Open Journal of Psychiatry, 7, 261-275.

https://doi.org/10.4236/ojpsych.2017.74023

Received: July 11, 2017

Accepted: August 14, 2017

Published: August 17, 2017

Copyright $\odot 2017$ by authors and Scientific Research Publishing Inc. This work is licensed under the Creative Commons Attribution International License (CC BY 4.0).

http://creativecommons.org/licenses/by/4.0/

\begin{abstract}
Aims: To investigate rates of attention-deficit hyperactivity disorder (ADHD) in patients with chronic pain attending a pain clinic, the effects of a screening measure for ADHD in patients with chronic pain, and the effects of ADHD drugs on both pain and ADHD symptoms. Methods: We retrospectively surveyed 110 patients with chronic pain visiting the Anesthesiology and Pain Relief Center at the University of Tokyo in Japan, who had also consulted a psychiatrist, between April 2012 and July 2015. Results: Of the total of 110 patients with chronic pain, 35 (31.8\%) were also diagnosed with ADHD, and the average Wender Utah Rating Scale (WURS) score among the ADHD patients was $39.0 \pm 22.1(n=25)$. Only $36.0 \%$ of these patients exceeded the cutoff value, suggesting that $64.0 \%$ of the patients with ADHD were not identified by screening with the WURS. Twenty-six patients initiated treatment with ADHD medication, with dosage adjustment completed in 21. Of these 21 patients 20 (95.0\%) had improved ADHD symptoms. Improved pain symptoms were observed in 14 patients $(66.6 \%)$, with a reduction in the pain numerical rating scale of $64.7 \% \pm 30.1 \%$. Conclusions: This is the first study investigating the comorbidity of ADHD and chronic pain at pain clinics showing a high level of comorbidity and amelioration of pain and ADHD symptoms with treatment. Careful interpretation is required when the WURS is used to screen patients with chronic pain.
\end{abstract}




\section{Keywords}

Atomoxetine, Attention Deficit Hyperactivity Disorder, Chronic Pain, Methylphenidate, Wender Utah Rating Scale

\section{Introduction}

Chronic pain is a condition in which the main symptom is persistent pain for more than 3 months after the acute phase [1]. In Japan, 13.4\% of the general population (approximately 17 million people) experience this symptom [2]. This represents a serious burden on Japanese society, with annual economic losses amounting to 370 billion yen [3]. Chronic pain occurs and persists due to complicated interactions between physical and psychosocial factors, which often makes it difficult to treat. Therefore, it is important to find more effective treatments that will improve the condition more rapidly, as this will have benefits from both health control and socio-economic perspectives.

Recent studies report that among patients with chronic pain, there are high numbers who have had multiple traffic accidents or who suffer from memory problems, both of which may suggest that they have attention-deficit hyperactivity disorder (ADHD). Indeed, it has been reported that treatment with ADHD medication (central nervous system stimulants) may effectively treat not only attention or memory problems, but also chronic pain symptoms [4].

It has also been suggested that fibromyalgia (FM) and chronic fatigue syndrome (CFS) may be related to ADHD [5] [6]. Therefore, ADHD should be included as a potential differential diagnosis during assessment for these disorders if patients complain of widespread muscle pain, tiredness, and sleep problems without significant physical abnormalities. A high rate of concurrent ADHD (25\% - 80\%) has been reported in individuals with FM [7] [8], and it has also been reported that $32.3 \%$ of patients with FM suffered from ADHD during early childhood, compared with $2.5 \%$ in a control group [9]. Moreover, patients with FM exhibit significant memory problems more often than healthy controls, and this is reportedly due to heightened distractibility among patients with FM [10]. Similarly, $50 \%-80 \%$ of patients with CFS exhibit impairments in memory, concentration, and attention [11]. Furthermore, it has been reported that many patients who consult a doctor for ADHD as their primary complaint have a previous diagnosis of FM or CFS [5]. Many of the patients with comorbid FM or CFS and ADHD have shown improvements in both ADHD and pain symptoms, when treated with ADHD medications (central nervous system stimulants) [5].

ADHD is a developmental disorder known to be associated with functional impairments in the dopamine and noradrenaline systems, leading to disorders in the executive, reward, and time-processing systems [12]. There are several subtypes of ADHD, including predominantly inattentive, predominantly hyperactive-impulsive, and combined subtypes, each of which persists from early child- 
hood. Patients with the predominantly hyperactive-impulsive subtype are easy to recognize due to their markedly problematic behaviors [5]. In contrast, in patients with the predominantly inattentive subtype, their ADHD symptoms are often masked by symptoms of depression and anxiety, meaning that their ADHD symptoms are often not correctly diagnosed and escape clinical awareness [5] [7]. The symptoms of ADHD can be improved with ADHD medications such as methylphenidate (a central nervous system stimulant) and atomoxetine (a non-central nervous system stimulant).

Given that medications for ADHD may improve chronic pain symptoms of the musculoskeletal system (e.g., lower back pain) among patients with FM and CFS, these medications may shed light on the treatment and management of chronic pain, which are often difficult. However, there are only a few previous reports on rates of patients with FM [8] [9] or CFS [13] who are also diagnosed with ADHD. Similarly, the limited studies performed to date have reported varied results with regard to the effects of central nervous stimulant treatments for ADHD on pain symptoms [5] [6] [7]. To our knowledge, there have been no reports on the rates of patients with chronic pain in the musculoskeletal system who are also diagnosed with $\mathrm{ADHD}$, or on their responsiveness to treatment. Furthermore, although some studies have reported the effects of central nervous system stimulant treatments for ADHD in patients with FM and CFS [5] [6] [7], there have been no reports on the treatment effects of non-central nervous system stimulant treatments for ADHD in such patients.

In the present study, patients with chronic pain whose symptoms were considered to be largely a result of psycho-social factors were recruited from a specialized pain clinic. All of these patients had been referred to a psychiatrist. The following were investigated: 1) The rate of patients with an ADHD diagnosis; 2) the effect of a screening measure for ADHD among patients with chronic pain; and 3) the effects of ADHD medications (central nervous system stimulants and non-central nervous system stimulants) on pain symptoms, as well as ADHD symptoms in individuals with both chronic pain and ADHD.

\section{Methods}

\subsection{Patients}

We retrospectively surveyed 110 patients ( 37 male, 73 female) with chronic pain who had been referred to a psychiatrist (S.K.) by an attending physician at the Anesthesiology and Pain Relief Center, University of Tokyo Hospital, Japan, between April 2012 and July 2015. All patients provided written informed consent, and their anonymity was preserved. The study was approved by the appropriate ethics committee of the University of Tokyo Hospital, Japan (application/ approval number 3678).

\subsection{Measures}

To assess treatment outcome, we used mean recorded pain intensity measured 
via the Numerical Rating Scale (NRS) [14]. The diagnosis of ADHD was made during an interview by a psychiatrist (S.K.) based on DSM-IV-TR criteria [15]. In addition, patients completed a self-assessment screening measure, the Wender Utah Rating Scale (WURS) [16]. The WURS evaluates ADHD symptoms experienced by patients in childhood and during their school years. It is scored on a 5-point scale and comprises 25 items that can effectively discriminate adults with ADHD from healthy controls [16]. A score exceeding the cutoff value of 46 indicates a high likelihood of the patient having adult ADHD.

Comorbidity with pervasive developmental disorder was assessed by a psychiatrist (S.K.) based on DSM-IV-TR criteria [15]. Retrospective assessment of clinical responses was made by a psychiatrist (S.K.) using the Clinical Global Impression Severity (CGI-S) subscale for ADHD severity and the Clinical Global Impression Improvement (CGI-I) subscale for treatment response [17]. The CGI-S rates severity of ADHD from $1-7$, where $1=$ normal, $2=$ borderline mentally ill, $3=$ mildly ill, $4=$ moderately ill, $5=$ markedly ill, $6=$ severely ill, and $7=$ extremely ill. The CGI-I assesses ADHD symptoms relative to baseline, where $1=$ very much improved, $2=$ much improved, $3=$ minimally improved, $4=$ no change, $5=$ minimally worse, $6=$ much worse, and $7=$ very much worse. Patients with chronic pain and concomitant ADHD received psychiatric treatment (pharmaceutical and cognitive-behavioral therapies) for ADHD symptoms, and improvement was assessed via the above-mentioned assessment measures.

\subsection{Statistical Analysis}

Initially, we used descriptive statistics to represent the frequency of ADHD diagnosis in patients with chronic pain. Next, we assessed the effects of pharmaceutical treatments on ADHD symptoms, as well as on chronic pain. We used the Jonckheere-Terpstra test to identify possible trends in improvement of ADHD symptoms and chronic pain. We analyzed relationships between improvement in NRS and gender and age (divided into 10-year strata) using Student's $t$-test and the Jonckheere-Terpstra test, respectively. Lastly, we investigated age differences between groups with and without 100\% improvement in the NRS, via Student's t-test. Values of $P<0.05$ were considered significant. All statistical analyses except the Jonckheere-Terpstra test were performed with JMP pro, version 11 (SAS Institute of Japan, Tokyo, Japan). The Jonckheere-Terpstra test was performed with SPSS version 23 (IBM Japan, Tokyo, Japan).

\section{Results}

\subsection{Patient Characteristics}

Of 110 patients with chronic pain who were referred to a psychiatrist, $35(31.8 \%)$ were diagnosed with ADHD and their characteristics are shown in Table 1. None of these patients had a previous diagnosis of ADHD. Among the patients with ADHD, 25 were female (mean age $46.9 \pm 16.8$ years) and 10 were male 
Table 1. Characteristics and treatment effects of the patients.

\begin{tabular}{|c|c|c|c|c|c|c|c|c|c|c|c|c|c|c|c|c|c|}
\hline No. & Sex & Age & $\begin{array}{c}\text { Main } \\
\text { complaint }\end{array}$ & $\begin{array}{l}\text { Pain } \\
\text { region }\end{array}$ & $\begin{array}{l}\text { Duration } \\
\text { (months) }\end{array}$ & WURS & IQ & Subtype & PDD & $\begin{array}{l}\text { Before } \\
\text { CGI-S }\end{array}$ & $\begin{array}{l}\text { After } \\
\text { CGI-S }\end{array}$ & CGI-I & $\begin{array}{c}\text { Before } \\
\text { NRS }\end{array}$ & $\begin{array}{l}\text { After } \\
\text { NRS }\end{array}$ & $\begin{array}{l}\text { Improvement } \\
\text { in NRS (\%) }\end{array}$ & Meth & Atom \\
\hline 1 & $\mathrm{~F}$ & 17 & $\begin{array}{l}\text { widespread } \\
\text { pain }\end{array}$ & $\begin{array}{l}\text { more than } \\
\text { three } \\
\text { major sites }\end{array}$ & 96 & NA & 67 & inattentive & - & 4 & 3 & 3 & 9 & 9 & & $36 \mathrm{mg}$ & \\
\hline 2 & $\mathrm{~F}$ & 25 & back pain & $\begin{array}{l}\text { lower back, } \\
\text { lumbar } \\
\text { spine, } \\
\text { sacrum, } \\
\text { coccyx }\end{array}$ & 14 & 26 & 89 & inattentive & - & 4 & 2 & 1 & 8 & 0 & 100.0 & $18 \mathrm{mg}$ & \\
\hline 3 & $\mathrm{~F}$ & 30 & $\begin{array}{l}\text { head and } \\
\text { cervical pain }\end{array}$ & $\begin{array}{l}\text { head, face, } \\
\text { mouth }\end{array}$ & 12 & 82 & 95 & inattentive & - & 4 & & & 9 & 9 & & $72 \mathrm{mg}$ & \\
\hline 4 & $\mathrm{~F}$ & 31 & $\begin{array}{l}\text { left hand, } \\
\text { cervical, } \\
\text { left upper } \\
\text { extremity pain }\end{array}$ & $\begin{array}{l}\text { more than } \\
\text { three } \\
\text { major sites }\end{array}$ & 132 & 56 & 103 & inattentive & - & 5 & 4 & 3 & 8 & 8 & & $36 \mathrm{mg}$ & \\
\hline 5 & $\mathrm{~F}$ & 32 & $\begin{array}{l}\text { widespread } \\
\text { pain }\end{array}$ & $\begin{array}{l}\text { more than } \\
\text { three } \\
\text { major sites }\end{array}$ & 8 & 21 & 81 & combined & - & 5 & & & 9 & & & & \\
\hline 6 & $\mathrm{~F}$ & 32 & $\begin{array}{l}\text { sternum, } \\
\text { back, lower } \\
\text { back pain }\end{array}$ & $\begin{array}{l}\text { more than } \\
\text { three } \\
\text { major sites }\end{array}$ & 24 & 69 & 77 & combined & - & 4 & & & 8 & & & & \\
\hline 7 & $\mathrm{~F}$ & 33 & $\begin{array}{l}\text { widespread } \\
\text { pain }\end{array}$ & $\begin{array}{l}\text { more than } \\
\text { three major } \\
\text { sites }\end{array}$ & 12 & 81 & 46 & inattentive & - & 4 & 2 & 2 & 10 & 8 & 20.0 & $72 \mathrm{mg}$ & \\
\hline 8 & $\mathrm{~F}$ & $37^{n}$ & $\begin{array}{c}\text { numbness and } \\
\text { pain in the } \\
\text { right arm }\end{array}$ & $\begin{array}{l}\text { upper } \\
\text { shoulder, } \\
\text { upper } \\
\text { limbs }\end{array}$ & 6 & NA & 104 & inattentive & - & 4 & & & 6 & & & & \\
\hline 9 & $\mathrm{~F}$ & 39 e & $\begin{array}{c}\text { right lower } \\
\text { extremity pain }\end{array}$ & $\begin{array}{l}\text { lower } \\
\text { limbs }\end{array}$ & 48 & NA & 81 & combined & - & 4 & & & 8 & & & & \\
\hline 10 & $\mathrm{~F}$ & 41 & $\begin{array}{l}\text { pain deep } \\
\text { inside the } \\
\text { clavicle }\end{array}$ & $\begin{array}{l}\text { thoracic } \\
\text { region }\end{array}$ & 15 & 13 & 91 & inattentive & - & 3 & & & 10 & 2 & 80.0 & CBT & CBT \\
\hline 11 & $\mathrm{~F}$ & 42 & $\begin{array}{l}\text { cervical, } \\
\text { shoulder, } \\
\text { elbow pain }\end{array}$ & $\begin{array}{l}\text { more than } \\
\text { three } \\
\text { major sites }\end{array}$ & 276 & 49 & 94 & inattentive & - & 4 & 2 & 1 & 7 & 0 & 100.0 & $72 \mathrm{mg}$ & $\begin{array}{l}120 \\
\mathrm{mg}\end{array}$ \\
\hline 12 & $\mathrm{~F}$ & 42 & $\begin{array}{c}\text { lower back } \\
\text { pain }\end{array}$ & $\begin{array}{l}\text { lower back, } \\
\text { lumbar } \\
\text { spine, } \\
\text { sacrum, } \\
\text { coccyx }\end{array}$ & 94 & NA & 113 & inattentive & - & 4 & 2 & 2 & 1 & 0 & 100.0 & $36 \mathrm{mg}$ & \\
\hline 13 & $\mathrm{~F}$ & 42 & $\begin{array}{l}\text { pain within } \\
\text { the ear }\end{array}$ & $\begin{array}{l}\text { head, face, } \\
\text { mouth }\end{array}$ & 9 & 17 & 64 & combined & - & 4 & & & 10 & & & $\mathrm{AE}$ & \\
\hline 14 & $\mathrm{~F}$ & 42 & $\begin{array}{l}\text { widespread } \\
\text { pain }\end{array}$ & $\begin{array}{l}\text { more than } \\
\text { three } \\
\text { major sites }\end{array}$ & 36 & 40 & 104 & inattentive & - & 4 & & & 7 & & & & \\
\hline
\end{tabular}




\section{Continued}

\begin{tabular}{|c|c|c|c|c|c|c|c|c|c|c|c|c|c|c|c|c|c|}
\hline 15 & $\mathrm{~F}$ & 47 & $\begin{array}{l}\text { cervical, } \\
\text { chest, knee } \\
\text { pain }\end{array}$ & $\begin{array}{l}\text { more than } \\
\text { three major } \\
\text { sites }\end{array}$ & 444 & 10 & 65 & combined & - & 6 & 5 & 3 & 10 & 10 & & $54 \mathrm{mg}$ & \\
\hline 16 & $\mathrm{~F}$ & 47 & $\begin{array}{l}\text { pain } \\
\text { around } \\
\text { the eyes }\end{array}$ & $\begin{array}{l}\text { head, } \\
\text { face, } \\
\text { mouth }\end{array}$ & 24 & NA & 106 & inattentive & - & 4 & 3 & 3 & 10 & 10 & & $36 \mathrm{mg}$ & \\
\hline 17 & $\mathrm{~F}$ & 52 & $\begin{array}{c}\text { pain } \\
\text { in both } \\
\text { shoulders }\end{array}$ & $\begin{array}{c}\text { upper } \\
\text { shoulder, } \\
\text { upper limbs }\end{array}$ & 24 & 40 & 104 & combined & - & 5 & 3 & 1 & 8 & 0 & 100.0 & $\mathrm{AE}$ & $80 \mathrm{mg}$ \\
\hline 18 & $\mathrm{~F}$ & 55 & $\begin{array}{l}\text { lower back } \\
\text { and lower } \\
\text { extremity pain }\end{array}$ & $\begin{array}{l}\text { lower back, } \\
\text { lumbar } \\
\text { spine, } \\
\text { sacrum, } \\
\text { coccyx }\end{array}$ & 120 & 54 & 76 & inattentive & - & 6 & 3 & 1 & 8 & 3 & 62.5 & $72 \mathrm{mg}$ & $\begin{array}{l}120 \\
\mathrm{mg}\end{array}$ \\
\hline 19 & $\mathrm{~F}$ & 60 & $\begin{array}{c}\text { lower back } \\
\text { pain }\end{array}$ & $\begin{array}{l}\text { lower back, } \\
\text { lumbar } \\
\text { spine, } \\
\text { sacrum, } \\
\text { coccyx }\end{array}$ & 60 & 47 & 95 & inattentive & - & 4 & 2 & 1 & 7 & 4 & 42.8 & $72 \mathrm{mg}$ & \\
\hline 20 & $\mathrm{~F}$ & 66 & $\begin{array}{l}\text { face, } \\
\text { cervical } \\
\text { pain }\end{array}$ & $\begin{array}{l}\text { head, face, } \\
\text { mouth }\end{array}$ & 84 & 3 & 123 & combined & - & 5 & 3 & 2 & 5 & 1 & 80.0 & $54 \mathrm{mg}$ & \\
\hline 21 & $\mathrm{~F}$ & 67 & $\begin{array}{l}\text { buttocks, } \\
\text { lower } \\
\text { extremity } \\
\text { pain }\end{array}$ & $\begin{array}{l}\text { lower } \\
\text { limbs }\end{array}$ & 4 & 24 & 127 & inattentive & - & 4 & & & 7 & 3 & 57.1 & CBT & CBT \\
\hline 22 & $\mathrm{~F}$ & 69 & $\begin{array}{l}\text { non-standard } \\
\text { toothache }\end{array}$ & $\begin{array}{l}\text { head, face, } \\
\text { mouth }\end{array}$ & 180 & 46 & 103 & combined & - & 6 & 4 & 2 & 6 & 6 & & $18 \mathrm{mg}$ & $80 \mathrm{mg}$ \\
\hline 23 & $\mathrm{~F}$ & 72 & $\begin{array}{l}\text { both hands, } \\
\text { right lower } \\
\text { extremity pain }\end{array}$ & $\begin{array}{l}\text { more than } \\
\text { three } \\
\text { major sites }\end{array}$ & 24 & 25 & 126 & inattentive & - & 3 & 2 & 2 & 8 & 6 & 25.0 & $36 \mathrm{mg}$ & \\
\hline 24 & $\mathrm{~F}$ & 76 & $\begin{array}{l}\text { lower back } \\
\text { and lower } \\
\text { extremity pain }\end{array}$ & $\begin{array}{l}\text { lower back, } \\
\text { lumbar } \\
\text { spine, } \\
\text { sacrum, } \\
\text { coccyx }\end{array}$ & 180 & NA & 102 & combined & - & 4 & & & 10 & & & & \\
\hline 25 & $\mathrm{~F}$ & 77 & $\begin{array}{c}\text { thoracic } \\
\text { pain }\end{array}$ & $\begin{array}{l}\text { thoracic } \\
\text { region }\end{array}$ & 192 & NA & 96 & inattentive & - & 3 & & & 8 & 8 & & $\mathrm{AE}$ & $\mathrm{AE}$ \\
\hline 26 & M & 27 & $\begin{array}{c}\text { anterior } \\
\text { chest pain }\end{array}$ & $\begin{array}{l}\text { thoracic } \\
\text { region }\end{array}$ & 96 & NA & 78 & combined & - & 4 & & & 7 & & & & \\
\hline 27 & M & 34 & $\begin{array}{l}\text { back and } \\
\text { neck pain }\end{array}$ & $\begin{array}{l}\text { lower back, } \\
\text { lumbar } \\
\text { spine, } \\
\text { sacrum, } \\
\text { coccyx }\end{array}$ & 300 & 24 & 91 & inattentive & + & 6 & 5 & 3 & 6 & 6 & & $36 \mathrm{mg}$ & \\
\hline 28 & M & 35 & headache & $\begin{array}{l}\text { head, face, } \\
\text { mouth }\end{array}$ & 72 & NA & 112 & inattentive & - & 3 & & & 6 & 0 & 100.0 & CBT & CBT \\
\hline 29 & M & 39 & $\begin{array}{l}\text { widespread } \\
\text { pain }\end{array}$ & $\begin{array}{l}\text { more than } \\
\text { three } \\
\text { major sites }\end{array}$ & 72 & 26 & 100 & inattentive & - & 4 & 2 & 1 & 7 & 4 & 42.8 & $72 \mathrm{mg}$ & $\begin{array}{l}120 \\
\mathrm{mg}\end{array}$ \\
\hline
\end{tabular}




\section{Continued}

\begin{tabular}{|c|c|c|c|c|c|c|c|c|c|c|c|c|c|c|c|c|c|}
\hline 30 & $\mathrm{M}$ & 40 & $\begin{array}{c}\text { widespread } \\
\text { pain }\end{array}$ & $\begin{array}{l}\text { more than } \\
\text { three } \\
\text { major sites }\end{array}$ & 27 & 54 & 104 & combined & - & 4 & 2 & 1 & 10 & 2 & 80.0 & $18 \mathrm{mg}$ & \\
\hline 31 & M & 44 & $\begin{array}{c}\text { lower back } \\
\text { pain }\end{array}$ & $\begin{array}{l}\text { lower back, } \\
\text { lumbar } \\
\text { spine, } \\
\text { sacrum, } \\
\text { coccyx }\end{array}$ & 120 & 41 & 130 & inattentive & + & 4 & 3 & & 7 & & & $\mathrm{AE}$ & \\
\hline 32 & M & 47 & $\begin{array}{c}\text { lower back } \\
\text { pain }\end{array}$ & $\begin{array}{l}\text { lower back, } \\
\text { lumbar } \\
\text { spine, } \\
\text { sacrum, } \\
\text { coccyx }\end{array}$ & 72 & 13 & 116 & combined & - & 4 & 3 & 3 & 9 & 5 & 44.4 & $\mathrm{AE}$ & $80 \mathrm{mg}$ \\
\hline 33 & M & 57 & $\begin{array}{c}\text { lower back } \\
\text { and lower } \\
\text { extremity } \\
\text { pain }\end{array}$ & $\begin{array}{l}\text { lower back, } \\
\text { lumbar } \\
\text { spine, } \\
\text { sacrum, } \\
\text { coccyx }\end{array}$ & 12 & 70 & 85 & combined & - & 4 & 2 & 2 & 6 & 4 & 30.0 & $18 \mathrm{mg}$ & \\
\hline 34 & M & 71 & $\begin{array}{c}\text { lower back } \\
\text { pain }\end{array}$ & $\begin{array}{l}\text { lower back, } \\
\text { lumbar } \\
\text { spine, } \\
\text { sacrum, } \\
\text { coccyx }\end{array}$ & 48 & NA & 100 & combined & - & 5 & & & 8 & & & $\mathrm{AE}$ & $\mathrm{AE}$ \\
\hline 35 & M & 79 & $\begin{array}{c}\text { lower back } \\
\text { pain }\end{array}$ & $\begin{array}{l}\text { lower back, } \\
\text { lumbar } \\
\text { spine, } \\
\text { sacrum, } \\
\text { coccyx }\end{array}$ & 300 & 39 & 130 & inattentive & - & 4 & 2 & 1 & 9 & 2 & 77.7 & $\mathrm{AE}$ & $\begin{array}{l}120 \\
\mathrm{mg}\end{array}$ \\
\hline
\end{tabular}

WURS, Wender Utah Rating Scale; PDD, pervasive developmental disorder; CGI-S, Clinical Global Impression Severity; CGI-I, Clinical Global Impression Improvement; NRS, Numerical Rating Scale; Meth, methylphenidate; CBT, cognitive-behavioral therapy; AE, adverse effect, NA: not available. CGI-S key: 1 $=$ normal, $2=$ borderline mentally ill, $3=$ mildly ill, $4=$ moderately ill, $5=$ markedly ill, $6=$ severely ill, and $7=$ extremely ill. CGI-I key: $1=$ very much improved, 2 = much improved, $3=$ minimally improved, $4=$ no change, $5=$ minimally worse, $6=$ much worse, $7=$ very much worse

(mean age $47.3 \pm 16.8$ years). As determined via the Wechsler Adult Intelligence Scale-III (WAIS-III) [18], the 35 patients had a mean IQ of $96.5 \pm 19.9$.

Completed WURS forms were received from 25 patients, and the mean score was $39.0 \pm 22.1$. With regard to ADHD subcategories, 21 patients were classified as the predominantly inattentive subtype and 14 as the combined subtype. Comorbid pervasive developmental disorder was only diagnosed in 2 patients. No patients met the DSM-IV-TR criteria for major depressive disorder.

Patients identified their primary sites of pain based on the International Association for the Study of Pain (IASP) classification [19], with 11 (31.4\%) answering "more than three major sites", 11 (31.4\%) answering "lower back, lumbar spine, sacrum, and coccyx", and 6 (17.1\%) answering "head, face, and mouth." These answers comprised $80.0 \%$ of the total. The mean pain intensity measured with the NRS was $7.8 \pm 1.8$. The mean duration of pain symptoms was $92.5 \pm$ 103.7 months ( $7.7 \pm 8.6$ years). 


\subsection{Treatment Effects on ADHD Symptoms and Chronic Pain}

Figure 1 shows the drug administration algorithm for the 35 patients diagnosed with ADHD. In this algorithm, in principle, a central nervous system stimulant is the first-choice treatment. If after subsequent evaluation the effect of the stimulant is deemed insufficient, the algorithm approves either switching to a noncentral nervous system stimulant, or co-administration of one drug from each class.

Twenty-six patients agreed to initiate pharmaceutical treatment with a central nervous system stimulant and/or a non-central nervous system stimulant. Following the withdrawal of 5 patients from pharmaceutical treatment due to adverse events or cancellation, dosage adjustment was completed in 21 patients. We assessed ADHD symptoms in these 21 patients via the CGI-I, and observed improvements in 20 (95.0\%). Improvements in pain symptoms as determined via the NRS were observed in $14 / 20$ (66.6\%).

Twenty patients with improved CGI-I for ADHD symptoms were divided into three subgroups according to their degree of improvement. Eight (40\%) were considered "very much improved", 6 (30\%) "much improved", and $6(30 \%)$ "minimally improved". Among 14 patients showing improvements in both ADHD symptoms and chronic pain, there was a mean reduction in pain NRS score of $64.7 \% \pm 30.1 \%$.

The mean dosages ( $\mathrm{mg} /$ day) of administered drugs and mean improvement rates (\%) were $40.5 \pm 23.0 \mathrm{mg} /$ day and $59.7 \% \pm 33.8 \%$ for methylphenidate alone

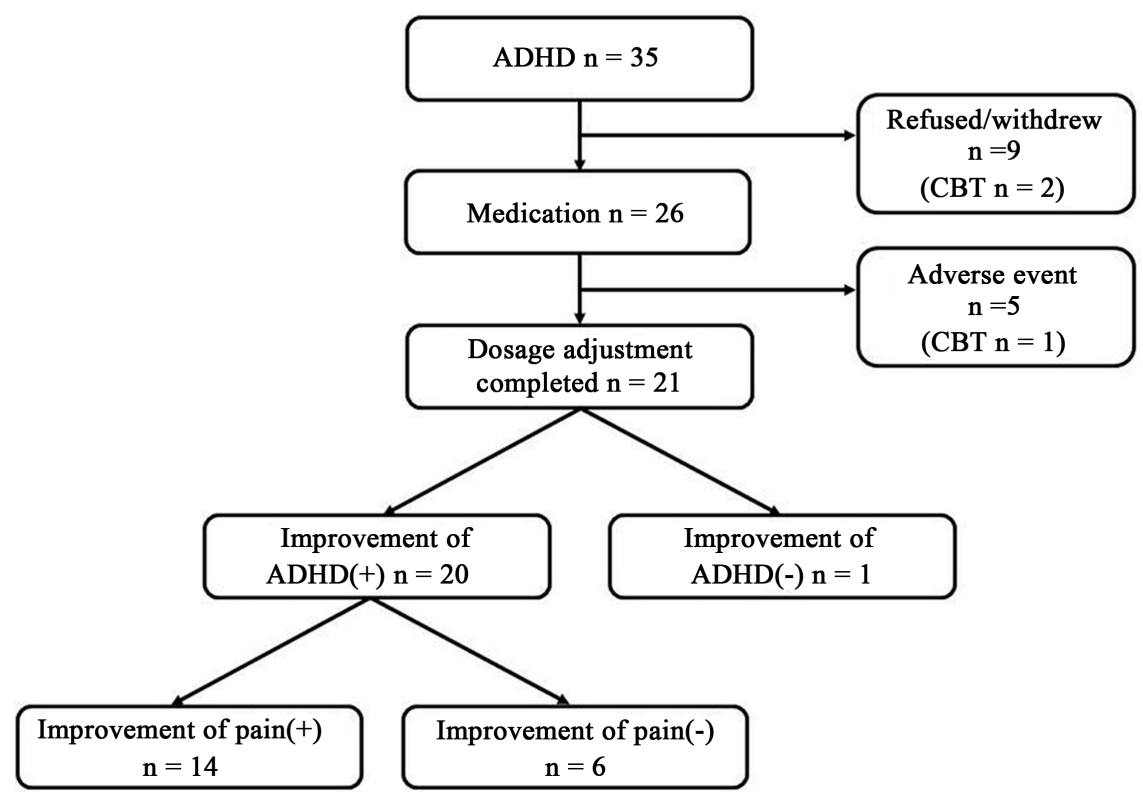

Figure 1. Flowchart of treatment selection in patients with chronic pain presenting with ADHD. Among 110 patients, 35 (31.8\%) were diagnosed with ADHD. Of these 35 patients, 21 completed drug adjustment. Of these 21 patients, ADHD symptoms improved in 20 (95\%). Pain symptoms also improved in most patients who completed dosage adjustment. ADHD, attention-deficit hyperactivity disorder; $\mathrm{CBT}$, cognitive-behavioral therapy. 
$(\mathrm{n}=8) ; 93.3 \pm 23.0 \mathrm{mg} /$ day and $74.0 \% \pm 27.9 \%$ for atomoxetine alone $(\mathrm{n}=3)$; and for concurrent administration of methylphenidate and atomoxetine $(\mathrm{n}=3)$ they were $72.0 \pm 0 \mathrm{mg} /$ day for methylphenidate, $120 \pm 0 \mathrm{mg} /$ day for atomoxetine, and $68.4 \% \pm 29.0 \%$. Among 14 patients who rejected pharmaceutical treatment or dropped out due to adverse events, 3 agreed to receive cognitivebehavioral therapy (CBT), and they responded well to CBT with a mean improvement rate of $79.0 \% \pm 21.4 \%$.

There were improvements in chronic pain in 17 patients (14 with pharmacotherapy and 3 with CBT). Improvement rates as determined via the NRS were $68.3 \% \pm 38.8 \%$ in patients with "mild" ADHD $(n=3), 63.2 \% \pm 29.6 \%$ in patients with "moderate" ADHD ( $\mathrm{n}=11)$, and $80.8 \% \pm 18.8 \%$ in patients with worse than "marked" ADHD $(\mathrm{n}=3)$. When we examined the relationship between ADHD severity and NRS-determined pain improvement using the JonckheereTerpstra test, there was no significant trend $(P=0.58)$. However, it was notable that the NRS-determined pain improvement rate exceeded $80 \%$ in patients with worse than "marked" ADHD severity.

The NRS improvement rate for men $(\mathrm{n}=6)$ was $62.5 \% \pm 27.3 \%$, and for women $(\mathrm{n}=11)$ it was $69.8 \% \pm 30.5 \%$, with no significant difference between the sexes ( $t$-test, $P=0.63)$. We also assessed NRS improvement rates according to age group. Those aged $\leq 40$ years $(\mathrm{n}=9)$ had a rate of $74.1 \% \pm 30.7 \%$; those aged 50 - 59 years $(n=3)$ had a rate of $64.2 \% \pm 35.0 \%$; those aged $60-69$ years $(n=3)$ had a rate of $60.0 \% \pm 18.8 \%$; and those aged 70 or more years $(n=2)$ had a rate of $51.3 \% \pm 37.3 \%$. Analysis of the relationship between age group and NRS improvement rate showed that improvement rate tended to decline as age increased, albeit non-significantly (Jonckheere-Terpstra test, $P=0.19$ ). The average age of the patients who showed 100\% NRS improvement $(\mathrm{n}=5)$ was $39.2 \pm$ 10.0 years, and the average age of patients who did not show $100 \%$ improvement $(\mathrm{n}=12)$ was $54.7 \pm 14.7$. The difference between these two groups was statistically significant ( $t$-test, $P=0.05$ ).

\section{Discussion}

In the present study, a psychiatrist (S.K.) at our pain clinic with extensive experience in the treatment of chronic pain was responsible for providing psychiatric diagnoses according to the DSM-IV-TR diagnostic criteria [15]. In the current study, 31.8\% of patients were diagnosed with ADHD, and none of these patients had been diagnosed with ADHD in the past. Although this figure is lower than the rate of comorbid ADHD (80\%) previously reported in a clinic specializing in FM [7], it is similar to the figure of $25 \%$ reported in patients with FM by Derksen et al. [8]. A recent meta-analysis estimated that the global prevalence of adult $\mathrm{ADHD}$ was $2.5 \%$ [20], while it has been estimated to be $1.7 \%$ in Japan [21]. The rate in the current study was 12.7 times that of the estimated global rate, and 19.3 times that of the estimated rate in Japan. ADHD prevalence among patients with refractory chronic pain at pain clinics is considered to be markedly high. 
Previous studies have reported a similar prevalence of ADHD among male and female adults [21] [22]. In the present study, there were more than twice as many female patients as male patients ( 25 vs. 10). This is consistent with previous reports that the frequency of pain is higher, the duration of pain is longer, and the tendency to seek treatment is higher in women [23]. It has also been reported that there are more female patients with FM or CFS who have comorbid ADHD than there are males [5]. A potential relationship with sex hormones has been suggested as the cause of these sex differences. Notably, it has been reported that in some women ADHD symptoms worsen during periods when the female hormone estrogen is reduced (for example before a menstrual period, after childbirth, and during menopause), which may aggravate inattention, a tendency to get upset, and emotional instability [24]. In the current study, there were 25 women with an average age of $46.9 \pm 16.8$ years, therefore female hormonal factors associated with menopause may have had an impact on the results.

Among 35 patients diagnosed with ADHD in the present study, the average WURS score for the 25 patients who completed the assessment was $39.0 \pm 22.1$. Only $36 \%$ of these exceeded the cutoff value, thus $64 \%$ of patients with ADHD were not identified by screening with the WURS. Subsections of the WURS do not directly relate to attention deficit symptoms, but use "academic underachievement" as a result of attention deficit as a proxy. In the current study, the mean IQ of patients with ADHD was $96.5 \pm 19.9$, and as they had not generally underachieved in school, their attention deficit symptoms may not have been reflected in their WURS score. Furthermore, a factor analysis of the Japanese version of the WURS did not reveal factors related to "attention deficit" [25]. Therefore, it has been suggested that while the WURS is a useful assessment tool to use to identify hyperactivity, it may not be appropriate for identifying cases of predominantly inattentive ADHD [26]. In particular, careful interpretation is required when the WURS is used to screen patients with chronic pain as well as attention deficit [7].

In the present study, of the patients who showed improvements in pain as well as ADHD symptoms, 8 received methylphenidate alone, 3 received atomoxetine alone, and 3 received concurrent administration of both drugs. This suggests the existence of subgroups among patients with ADHD and concurrent chronic pain, who differ in their neurological conditions. As mentioned above, FM and CFS can reportedly be improved by central nervous system stimulants [5] [6] [7], and administration of atomoxetine and central nervous system stimulants has been considered an appropriate treatment strategy to alleviate executive dysfunction in FM [27]. There has been speculation about the potential mechanisms underlying these changes. Patients with ADHD who exhibit inattention symptoms are highly sensitive to the environment, and have difficulty "filtering out" unpleasant stimuli and showing intolerance to mild tactile stimuli [28]. They are prone to overreacting in stressful environments, and it has been suggested that they are prone to developing chronic pain because their cognitive 
impairments make it difficult for them to filter out physical stimuli (including pain and tinnitus) throughout their bodies [6]. Central nervous system stimulants are considered to effectively enhance the filtering function by increasing the signal-to-noise ratio, allowing patients to properly discriminate various irritating stimuli and improving pain symptoms [29].

In the present study, the average improvement rates in NRS scores for the different categories of the CGI-I were $75.7 \% \pm 24.3 \%$ for "very much improved" ( $\mathrm{n}$ $=8), 51.0 \% \pm 36.5 \%$ for "much improved" ( $\mathrm{n}=5$ ), and $44.4 \%$ for "minimally improved" $(\mathrm{n}=1)$. This suggests that patients achieving greater improvement in ADHD symptoms may exhibit greater improvements in pain, too. Nine patients (25.7\%) either declined or discontinued with drug treatment for a variety of reasons, including "I do not accept a diagnosis of ADHD", "I do not want to receive drug treatment", and "I could not wait until the treatment took effect", among others. In some cases, pain symptoms were not improved but the drug treatment was effective for ADHD symptoms. This situation may have resulted from the dosage not being adjusted adequately, which may in turn have been due to inadequate dosing management or a lack of patience with regard to waiting to determine the effects of gradual dose increments. It is possible that devising better ways of informing patients about their diagnosis and the management of drug regimens may facilitate further improvements.

Notably, in 3 cases where drug treatment was ineffective in the current study, CBT (assertive training and operant conditioning) was conducted and improvements in pain symptoms were achieved. This suggests that psychological intervention alone may be able to improve a patient's condition even if they have concurrent chronic pain and ADHD. Thus, the optimal treatment modality should be considered on a case-by-case basis.

Two main subtypes of ADHD were diagnosed in the patients in the current study, including 21 patients (60\%) with the predominantly inattentive subtype, and $14(40 \%)$ with the combined subtype. This is consistent with a previous report that most patients with FM or CFS who have comorbid ADHD have either the predominantly inattentive or the combined subtype [6] [7]. However, epidemiological studies of the prevalence of adult ADHD suggest that $78.5 \%$ of patients have the predominantly inattentive subtype, [21], so this could also be considered consistent with general trends in adult ADHD cases. No patients in the current study had previously been diagnosed with ADHD. This may be because patients with the predominantly inattentive subtype do not exhibit noticeable symptoms, and patients with the combined subtype who have hyperactivity also tend to exhibit reduced hyperactive-impulsive symptoms as they grow older [30]. This makes such symptoms difficult to observe. Furthermore, patients often state that they cannot keep still because of pain, making it all the more difficult to recognize that ADHD is the cause of their hyperactivity. In addition, because pain clinicians are generally not experienced in the diagnosis of $\mathrm{ADHD}$, in many patients symptoms of ADHD may go unnoticed during assessments. 
Many patients with chronic pain pay excessive attention to pain stimuli, which in turn increases the feeling of pain [31]. According to the gate control theory [32], this is due to the fact that attention to pain inhibits the descending pain inhibitory system, thereby increasing information that reaches the brain. For this reason, a technique called "distraction" which diverts attention from a pain stimulus is recommended in CBT for chronic pain [31]. Patients with ADHD are easily distracted by matters that in ordinary circumstances would be outside their interest. Conversely, they also devote excessive attention to matters that interest them. We suspect that accordingly, when excessive attention is paid to an unpleasant pain stimulus, the effect of the descending pain inhibitory system diminishes and the feeling of pain increases.

In our experience, patients with chronic pain can be broadly classified into two types depending on activity patterns. One type tends to reduce their amount of activity for fear of pain exacerbation, and the other type desires to continue their activities without taking breaks [31]. The former tend to engage in catastrophic thinking about pain and fear associated with performing various physical activities. When patients with ADHD are exposed to stressors such as pain, it induces excess norepinephrine and dopamine release in their prefrontal cortices, which often makes them anxious due to hyper-arousal [27], and causes them to fear pain. In our clinical experience, patients with the predominantly inattentive subtype of ADHD tend to exhibit activity reduction. The other kind of patient is known to engage in an overly active behavioral pattern, undertaking too much exercise rather than gradually increasing exercise intensity. As a result, pain is aggravated and subsequently they must stop activities. This has been dubbed the "yo-yo pattern" [31]. Given these considerations, "pacing" is recommended as a technique to gradually increase exercise intensity in accordance with a plan during CBT for patients with chronic pain [31]. When this type of patient is asked why they engage in too much exercise all at once, they will usually assert that they do not have the patience to gradually increase the amount of exercise they engage in, and that they cannot keep still in order to promptly alleviate pain. This represents the presence of strong impulsiveness and hyperactivity. In our clinical experience, combined ADHD patients tend to exhibit this hyperactivity type.

Some patients with chronic pain often express stronger anger towards their family members, doctors, employers, and even themselves than individuals without chronic pain do, and their feelings of anger are reportedly strongly correlated with the intensity of their chronic pain, self-conscious impairments, and the frequency of their pain behaviors [33]. The brain circuit related to anger expression reportedly overlaps with the circuit related to pain [34]. As a result of this overlap, previous episodes associated with anger experienced by patients with ADHD may recur vividly, and they often talk about a feeling of strong anger as if they have just experienced the emotion even several years after the preceding episode. It may be that such irrepressible feelings of anger induce physical pain. 


\section{Conclusion}

In summary, characteristics of patients with ADHD such as over-attentiveness to pain and being overly active may facilitate a vulnerability to developing chronic pain. "Excessive attention," "hyperactivity," and "anger" are observed in many patients with chronic pain, particularly those with ADHD. To our knowledge, this is the first study to report on the comorbidity of ADHD and chronic pain at a pain clinic. However, further research is required to replicate our results with regard to $\mathrm{ADHD}$ prevalence among patients with chronic pain who visit pain clinics.

\section{Acknowledgements}

The study received no external funding. We would like to thank Editage (http://www.editage.com/) for English language editing and Publication Support.

\section{Disclosure Statement}

The authors declare that there are no conflicts of interest.

\section{References}

[1] Treede, R.D., Rief, W., Barke, A. Aziz, Q., Bennett, M.I., Benoliel, R., Cohen, M., Evers, S., Finnerup, N.B., First, M.B., Giamberardino, M.A., Kaasa, S., Kosek, E., Lavand'Homme, P., Nicholas, M., Perrot, S., Scholz, J., Schug, S., Smith, B.H., Svensson, P., Vlaeyen, J.W. and Wang, S.J. (2015) A Classification of Chronic Pain for ICD-11. Pain, 156, 1003-1007. https://doi.org/10.1097/j.pain.0000000000000160

[2] Hattori, S. (2006) The Prevalence of Chronic Pain in Japan. Nihon Yakurigaku Zasshi, 127, 176-180. https://doi.org/10.1254/fpj.127.176

[3] American Chamber of Commerce in Japan (2012) National Survey on Prevention, Early Detection and the Economic Burden of Disease in Japan. http://www.janssen.com/japan/press-release/20120418

[4] Kaplan, M.S. and Kaplan, L.R. (2006) Why Do Chronic Pain Patients Have Multiple Accidents? Pain Medicine, 7, 466. https://doi.org/10.1111/j.1526-4637.2006.00208_1.x

[5] Young, J.L. and Redmond, J.C. (2007) Fibromylagia, Chronic Fatigue, and Adult Attention Deficit Hyperactivity Disorder in the Adult: A Case Study. Psychopharmacology Bulletin, 40, 118-126.

[6] Young, J.L. (2013) Chronic Fatigue Syndrome: 3 Cases and a Discussion of the Natural History of Attention-Deficit/Hyperactivity Disorder. Postgraduate Medicine, 125, 162-168. https://doi.org/10.3810/pgm.2013.01.2631

[7] Young, J.L. and Redmond, J.C. (2007) ADHD and Fibromyalgia: Related Conditions? In: Ostalecki, S., Ed., Fibromyalgia: The Complete Guide from Medical EXperts and Patients, Jones and Bartlett, Sudbury, Massachusetts, 165-178.

[8] Derksen, M.T., Vreeling, M.J. and Tchetverikov, I. (2015) High Frequency of Adult Attention Deficit Hyperactivity Disorder among Fibromyalgia Patients in the Netherlands: Should a Systematic Collaboration between Rheumatologists and Psychiatrists Be Sought? Clinical and Experimental Rheumatology, 33, S141.

[9] Reyero, F., Ponce, G., Rodriguez-Jimenez, R., Fernandez-Dapica, P., Taboada, D., Martin, V., Navio, M., Jimenez-Arriero, M.A., Hoenicka, J. and Palomo, T. (2011) High Frequency of Childhood ADHD History in Women with Fibromyalgia. Euro- 
pean Psychiatry: The Journal of the Association of European Psychiatrists, 26, 482-483. https://doi.org/10.1016/j.eurpsy.2010.03.012

[10] Leavitt, F. and Katz, R.S. (2006) Distraction as a Key Determinant of Impaired Memory in Patients with Fibromyalgia. The Journal of Rheumatology, 33, 127-132.

[11] Short, K., McCabe, M. and Tooley, G. (2002) Cognitive Functioning in Chronic Fatigue Syndrome and the Role of Depression, Anxiety, and Fatigue. Journal of Psychosomatic Research, 52, 475-483. https://doi.org/10.1016/S0022-3999(02)00290-8

[12] Sonuga-Barke, E., Bitsakou, P. and Thompson, M. (2010) Beyond the Dual Pathway Model: Evidence for the Dissociation of Timing, Inhibitory, and Delay-Related Impairments in Attention-Deficit/Hyperactivity Disorder. Journal of the American Academy of Child and Adolescent Psychiatry, 49, 345-355. https://doi.org/10.1097/00004583-201004000-00009

[13] Sáez-Francàs, N., Alegre, J., Calvo, N., Antonio Ramos-Quiroga, J., Ruiz, E., Hernández-Vara, J. and Casas, M. (2012) Attention-Deficit Hyperactivity Disorder in Chronic Fatigue Syndrome Patients. Psychiatry Research, 200, 748-753. https://doi.org/10.1016/j.psychres.2012.04.041

[14] Jensen, M.P. and Karoly, P. (2011) Self-Report Scales and Procedures for Assessing Pain in Adults. In: Turk, D.C. and Melzack, R., Eds., Handbook of Pain Assessment, 3rd Edition, Guilford Press, New York, 15-34.

[15] American Psychiatric Association (2000) Diagnostic and Statistical Manual of Mental Disorders. 4th Edition, Text Revision, American Psychiatric Association, Washington DC.

[16] Ward, M.F., Wender, P.H. and Reimherr, F.W. (1993) The Wender Utah Rating Scale: An Aid in the Retrospective Diagnosis of Childhood Attention Deficit Hyperactivity Disorder. The American Journal of Psychiatry, 150, 885-890.

[17] National Institute of Mental Health (1985) CGI (Clinical Global Impression) Scale-NIMH. Psychopharmacology Bulletin, 21, 839-844.

[18] Wechsler, D. (1997) Wechsler Adult Intelligence Scale. 3rd Edition, The Psychological Corporation, San Antonio, TX.

[19] International Association for the Study of Pain (2011) Classification of Chronic Pain. 2nd Edition.

http://www.iasp-pain.org/files/Content/ContentFolders/Publications2/Classificatio nofChronicPain/Part_I-Scheme+Topics.pdf

[20] Thapar, A. and Cooper, M. (2016) Attention Deficit Hyperactivity Disorder. Lancet, 387, 1240-1250. https://doi.org/10.1016/S0140-6736(15)00238-X

[21] Nakamura, K., Ohnishi, M., Uchiyama, S., Takebayashi, K., Ninomiya, T., Suzuki, K., Tsujii, M. and Mori, N. (2013) Epidemiological Survey of Attention Deficit Hyperactivity Disorder (ADHD) in Japan. Japanese Journal of Psychiatric Treatment, 28, 155-162.

[22] Resnick, R.J. (2000) The Hidden Disorder: A Clinician's Guide to Attention Deficit Hyperactivity Disorder in Adults. American Psychological Association, Washington DC. https://doi.org/10.1037/10351-000

[23] Fillingim, R.B., King, C.D., Ribeiro-Dasilva, M.C., Rahim-Williams, B. and Riley 3rd., J.L. (2009) Sex, Gender, and Pain: A Review of Recent Clinical and Experimental Findings. The Journal of Pain: Official Journal of the American Pain Society, 10, 447-485. https://doi.org/10.1016/j.jpain.2008.12.001

[24] Rodin, G.C. and Lithman, J.R. (2002) Fibromyalgia in Women with AD/HD. In: Nadeau, K.M. and Quinn, P.O., Eds., Understanding Women with $A D / H D$, Advantage Books, Altamonte Springs, Florida, 190-226. 
[25] Shimotsu, S., Izutsu, T., Matsumoto, T., Okada, T., Kojimoto, M., Noguchi, H., Kikuchi, A., Takizawa, M. and Yoshikawa, K. (2006) Self-Esteem and Childhood Histories of Hyperactivity in Junior High School Students: An Evaluation Using the Wender Utah Rating Scale. Seishin Igaku, 48, 371-380.

[26] Ramsay, J.R. and Rostain, A.L. (2007) Cognitive-Behavioral Therapy for Adult ADHD. Routledge, New York.

[27] Stahl, S.M. (2013) Stahl's Essential Psychopharmacology: Neuroscientific Basis and Practical Applications. 4th Edition, Cambridge University Press, Cambridge.

[28] Mangeot, S.D, Miller, L.J., McIntosh, D.N., McGrath-Clarke, J., Simon, J., Hagerman, R.J. and Goldson, E. (2001) Sensory Modulation Dysfunction in Children with Attention-Deficit-Hyperactivity Disorder. Developmental Medicine and Child Neurology, 43, 399-406. https://doi.org/10.1017/S0012162201000743

[29] Sikström, S. and Söderlund, G. (2007) Stimulus-Dependent Dopamine Release in Attention-Deficit/Hyperactivity Disorder. Psychological Review, 114, 1047-1075. https://doi.org/10.1037/0033-295X.114.4.1047

[30] Biederman, J., Mick, E. and Faraone, S.V. (2000) Age-Dependent Decline of Symptoms of Attention Deficit Hyperactivity Disorder: Impact of Remission Definition and Symptom Type. The American Journal of Psychiatry, 157, 816-818. https://doi.org/10.1176/appi.ajp.157.5.816

[31] Flor, H. and Turk, D.C. (2011) Chronic Pain: An Integrated Biobehavioral Approach. IASP Press, Seattle.

[32] Melzack, R. and Wall, P.D. (1965) Pain Mechanisms: A New Theory. Science, 150, 971-979. https://doi.org/10.1126/science.150.3699.971

[33] Kerns, R.D., Rosenberg, R. and Jacob, M.C. (1994) Anger Expression and Chronic Pain. Journal of Behavioral Medicine, 17, 57-67. https://doi.org/10.1007/BF01856882

[34] Bruehl, S., Burns, J.W., Chung, O.Y. and Chont, M. (2009) Pain-Related Effects of TraitAnger Expression: Neural Substrates and the Role of Endogenous Opioid Mechanisms. Neuroscience and Biobehavioral Reviews, 33, 475-491.

https://doi.org/10.1016/j.neubiorev.2008.12.003 